\title{
Interproximal Space Recovery Using an Orthodontic Elastic Separator Before Prosthetic Restoration: A Case Report
}

\author{
Luciana Lira MENEGHEL ${ }^{1}$ \\ Linda $\mathrm{WANG}^{2}$ \\ Murilo Baena LOPES ${ }^{1}$ \\ Alcides GONINI JÚNIOR ${ }^{1}$ \\ ${ }^{1}$ Department of Restorative Dentistry, UNOPAR - University of North Paraná, Londrina, PR, Brazil \\ ${ }^{2}$ Department of Operative Dentistry, Endodontics and Dental Materials, Bauru Dental School, \\ USP - University of São Paulo, Bauru, SP, Brazil
}

\begin{abstract}
The presence of a dental contact point is essential to maintain normal occlusion and to preserve the health of periodontal structures. Occasionally dental caries could compromise the interproximal contact point, leading to migration of the adjacent teeth with consequent retention of food, gingival inflammation, pocket formation, bone loss and dental mobility. In order to achieve an adequate restorative treatment, reestablishment of interproximal space is necessary. This report describes the interproximal space recovery between the maxillary first and second molars of a 45 -year-old female patient before tooth reconstruction. In this case, an orthodontic elastic separator was indicated as an alternative to fixed orthodontic appliances in order to recover the necessary space. The technique was proven efficient, effective, economical, easy to perform and, above all, less invasive than other methods. The interproximal space was regained and a ceramic onlay was cemented for restoring the maxillary second molar. Periodical clinical and radiographic follow-up should be maintained to ensure long-term success.
\end{abstract}

Key Words: tooth crowding, interdental space, elastic separating, minor orthodontics.

\section{INTRODUCTION}

An ideal coexistence between dental restoration and the surrounding periodontal structures is imperative for a successful restorative procedure. Unfortunately this situation is sometimes neglected due to lack of knowledge of the physiological concepts or to reduce costs and clinical time (1). When unfavorable situations exist, such as proximity between roots, this healthy coexistence is impossible to be completely achieved (2).

When teeth are too close, the interproximal areas present non-keratinous epithelium and are more permeable to bacterial toxins. To avoid this clinical situation the interproximal space must be recovered before dental restoration, thus permitting the keratinization of the epithelium creating conditions for the effective control of bacterial plaque (3).
In order to create a space for better sculpturing with adequate functional results of the dental restoration (4), a previous periodontal or orthodontic intervention is necessary to increase the interproximal space. As an option, a surgical management of the restorative alveolar interface (RAI) can be applied, which requires root scaling and planning, as well as osteotomy and osteoplasty in order to modify the anatomy of interproximal area. In this case, a modification of root surface is provided simultaneously with surgical crown lengthening (5). As a second option, the necessary interproximal space can be created by minor orthodontic movement. Regaining space by using elastic orthodontic separators has been described $(6,7)$.

This report describes a case in which orthodontic therapy using an elastic separator was used as an alternative to fixed orthodontic appliance for recovering the necessary interproximal space. 


\section{CASE REPORT}

A 45-year-old woman was concerned about the condition of her maxillary left first molar, which presented a temporary restoration placed 2 months before, just after the endodontic treatment. The clinical examination revealed extensive crown destruction, including the occlusal, palatal and proximal faces. Radiographic examination revealed reduced interproximal space, due to the proximity between the maxillary right and left first molars (Fig. 1). Based on the conditions of the remaining walls, an indirect onlay restoration was indicated, but sufficient space had to be created to accommodate the gingival tissues and permit interdental hygiene.

The temporary restoration was removed and a core build up was prepared with a resin-modified glass ionomer cement layer (Vitremer; 3M ESPE, St. Paul, MN, USA) prior to a microhybrid composite resin layer

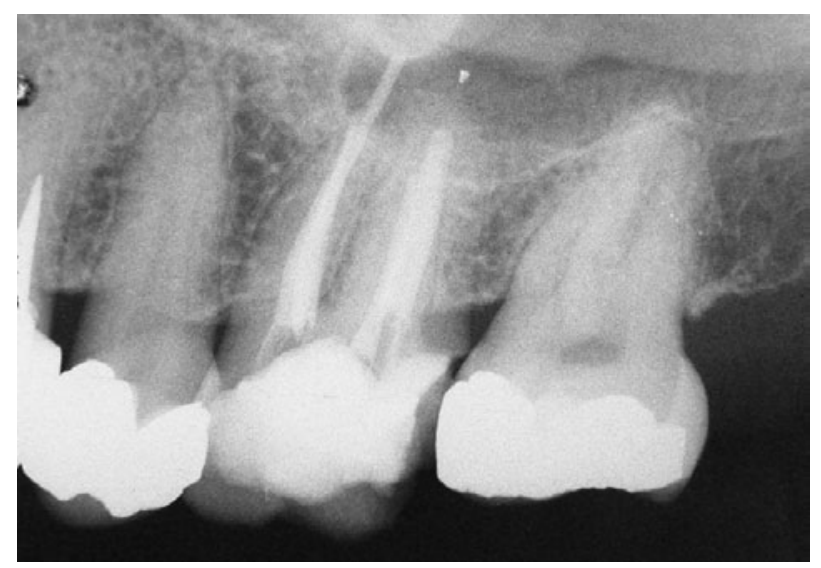

Figure 1. A periapical radiograph was obtained to identify the proximal space loss between teeth 26 and 27.

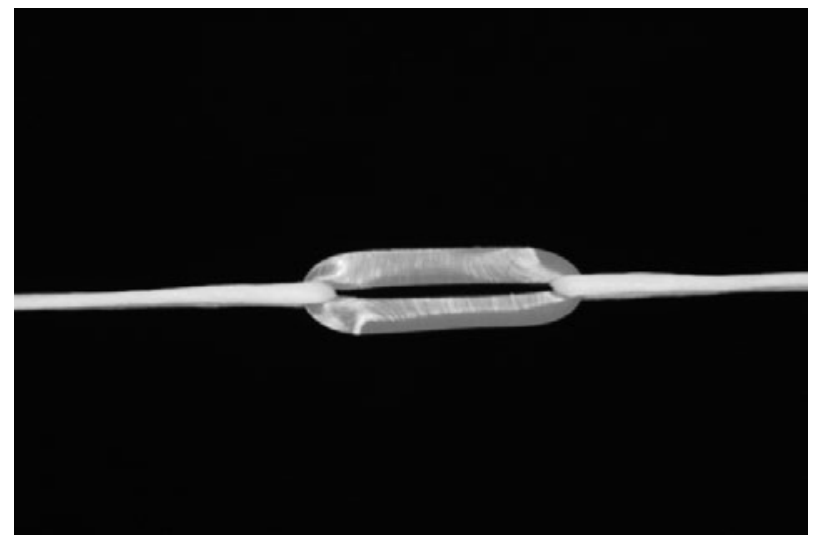

Figure 3. Orthodontic elastic separator stretched by dental floss.
(P60;3M ESPE). The cavity preparation was performed with a \#4138 high-speed diamond bur (KG Sorensen, São Paulo, SP, Brazil) (Fig. 2).

Then, a temporary restoration made with autopolymerizing acrylic resin (Duralay; Reliance Dental Man. Comp., Worth, IL, USA) was fixed with a calcium hydroxide cement (Dycal; Dentsply Ind. Com. Ltda, Petrópolis, RJ, Brazil), re-establishing the proximal contact point. An orthodontic elastic separator (Morelli Ortodontia, Sorocaba, SP, Brazil) with $4.8 \mathrm{~mm}$ diameter was stretched with 2 pieces of dental floss (Fig. 3) and then inserted between the maxillary molars (Fig. 4).

The patient was instructed to return after 1 week. During this period, the patient was asked to restrict mastication at the area in order to avoid complete displacement of the device and not to use dental floss in order to prevent displacement or introduction of the elastic into the gingival sulcus.

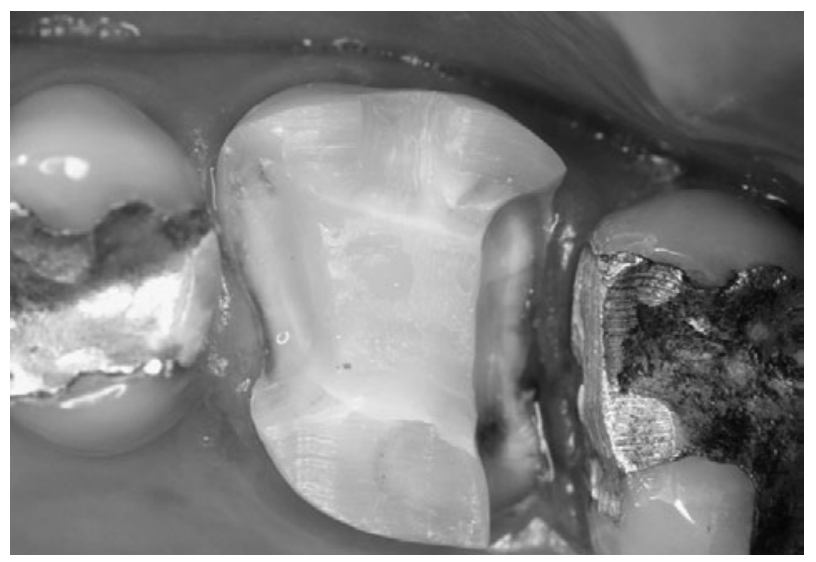

Figure 2. Final cavity configuration involving vestibular and palatal cusps.

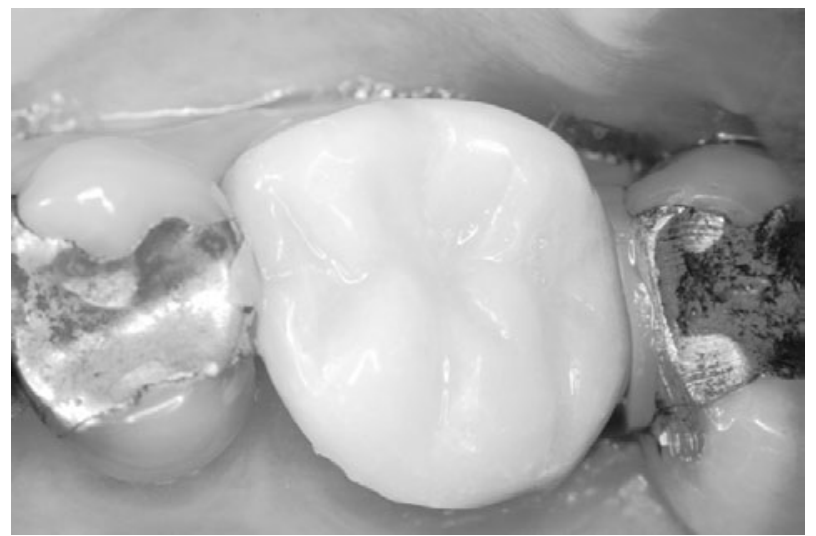

Figure 4. Orthodontic elastic separator inserted into the interproximal space. 
At the following appointment, the elastic was removed and a 1-mm interproximal space could be observed (Fig. 5). The contact point was reestablished on the distal face of the temporary restoration with acrylic resin. After temporary cementation, a new elastic separator was placed and the patient instructed to return within one week.

Clinical examination showed that the distal displacement of the second molar became evident after the second week. At this point, the movement could be radiographically confirmed by the increased thickness of the hard lamina close to the mesial marginal crest and decreased thickness of the distal hard lamina (Fig. 6).

The contact point was established again in the temporary restoration in order to provide an adequate biological relation between the periodontal tissue and the dental structure for the healing period, which usually takes place in 60 days. After this period, a healthy, keratinized proximal gingival margin was observed (Fig. 7).

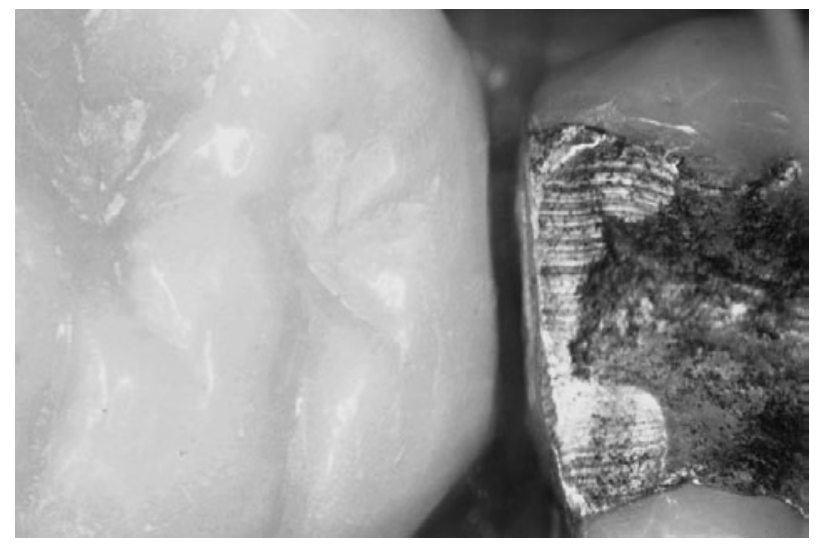

Figure 5. Interproximal space observed after one week.

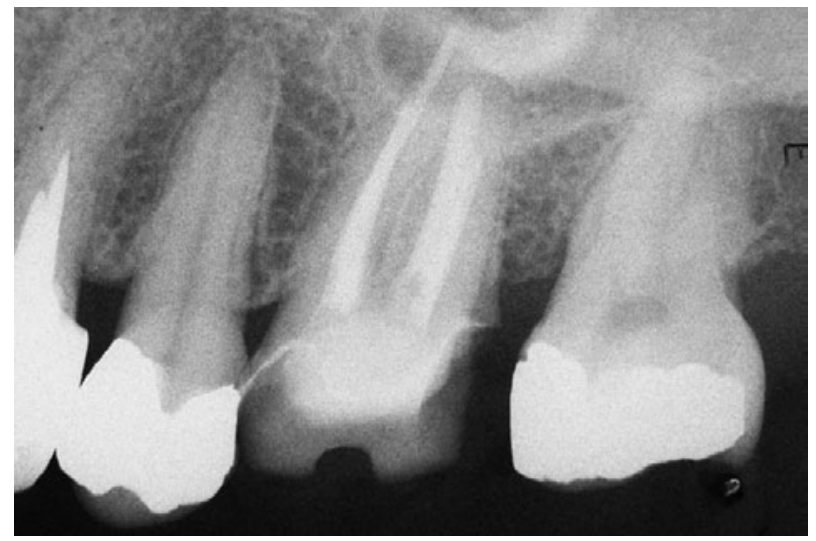

Figure 6. Radiographic aspect to ensure the properly final interproximal space.
Definitive impression was taken using stock tray and silicon impression material (Express; 3M ESPE) to obtain a working cast, in which the ceramic onlay was made (IPS EMPRESS; Ivoclar-Vivadent AG, Schaan, Liechtenstein, Germany).

After checking the proximal contacts and the marginal discrepancies, the ceramic onlay was cemented with a dual cured resin cement (Rely XARC; 3M ESPE) according to manufacturer's instructions. The occlusal contacts were checked after cementation and the patient was advised to avoid chewing hard-based diet for $24 \mathrm{~h}$ in order to allow adequate resin cement polymerization (8).

\section{DISCUSSION}

Compared to the fixed orthodontic therapy, this technique has a limitation: the elastic separator produces a rotational movement, which could induce a slight oblique extrusion $(1,3,7)$. Therefore, it is extremely important to check the occlusion and, when necessary, make the occlusal adjustments during the treatment (9). On the other hand, placement of fixed orthodontic appliance could influence on microbiological and clinical periodontal parameters, which could delay the healing of the distal gingival margin (10).

Brass wire separators could be used instead of elastomeric separators. Pain from wire separators occurs over 7 days, whereas elastomeric separators produce more separation comparatively and the peak of pain occurs on the first 2 days after insertion (11).

Another situation that deserves clinical follow-up is hypermobility of teeth. If it occurs, the tooth tends to return to normal when the temporary restoration is adjusted and the movement stimulus is removed (1).

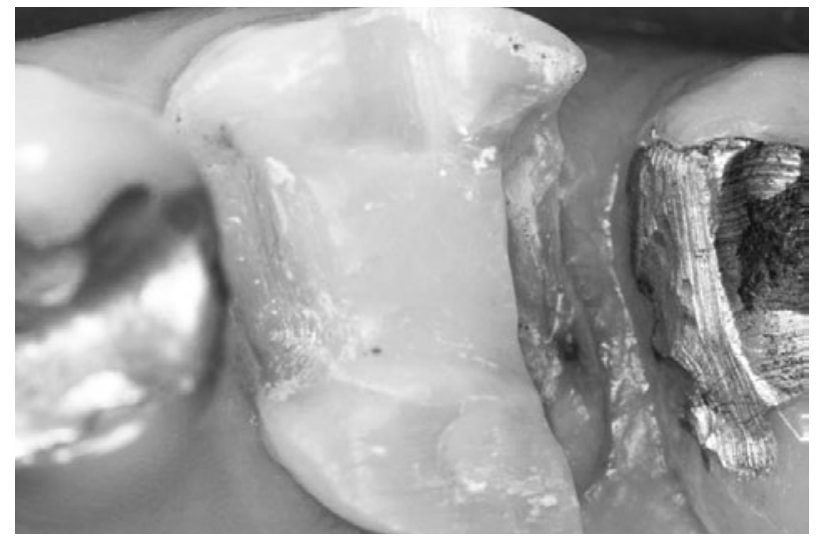

Figure 7. Clinical aspect of healthy and keratinized proximal gingival margin observed after 60 days. 
It is also important to observe that the treatment time to obtain the necessary interproximal space is different from patient to patient. Some cases require more sessions to reestablish the desired biological space than the case hereby reported. Therefore, the decision to interrupt or extend treatment should always be based on the space observed clinically and radiographically $(12,13)$.

It may be concluded that restorative procedures should not be carried out in the presence of periodontal disease nor cause irritation to the sub-sulcular anatomic structures. In order to achieve an adequate restorative treatment, maintenance of adequate interdental anatomy is mandatory. Regardless of the restorative technique used in each case, an accurate diagnosis is determinant for treatment success. If not re-established properly, proximal contours entail food retention, gingival inflammation, pocket formation, bone loss and finally dental mobility. The technique presented in this report, using an orthodontic elastic separator, was proven efficient, effective and economical, easy to perform and less invasive than other methods. Periodical clinical and radiographic follow-up should be maintained to ensure long-term success.

\section{RESUMO}

A presença dos pontos de contato dentais é essencial para a manutenção da oclusão habitual e da saúde das estruturas periodontais. Ocasionalmente as cáries dentárias podem comprometer o ponto de contato interproximal, induzindo a migração de dentes adjacentes com conseqüente retenção de alimento, inflamação gengival, formação de bolsa periodontal, perda óssea e mobilidade dental. A fim de realizar um tratamento restaurador adequado, o restabelecimento do espaço interproximal é necessário. O presente relato descreve a recuperação do espaço interproximal entre molares de uma paciente de 45 anos de idade antes da reconstrução dentária. Neste caso, um elástico ortodôntico separador foi indicado como alternativa aos dispositivos ortodônticos fixos no restabelecimento do espaço necessário. A técnica utilizada provou ser eficiente, efetiva e econômica, e principalmente menos invasiva e fácil de ser realizada. Contudo para que o sucesso clínico se estabeleça ao longo do tempo, faz-se necessário um controle clínico e radiográfico.

\section{REFERENCES}

1. Keesee SM, Baty DL, Cameron Sm, Lefter TB, Morris WJ. A technique for achieving prerestorative minor tooth movement with orthodontic separators. J Prosthet Dent 2002;88:544-547.

2. Stoll LB, Novaes AB, Lopes RA. Modification of col shape and interproximal area after periodontal surgery associated with the restorative alveolar interface (RAI) technique. Histological study in dogs. Braz Dent J 2001;12:147-153.
3. Sfondrini MF, Cacciafesta V, Sfondrini G. Upper molar distalization: a critical analysis. Orthod Craniof Res 2002;5:114126.

4. Dias LZS, Novaes Junior AB, Novaes AB. Prosthesis periodontics relationship II. Increase of clinical crown and surgery for prosthetic purpose. Braz Dent J 1991;2:19-26.

5. Ross SE, Gargiulo A. The surgical management of the restorative alveolar interface. Int J Periodontics Restorative Dent 1982;2:831.

6. VanderWeele RA, Broome JC, Ramer JP. Regaining space by using elastic orthodontic separators. Gen Dent 1998;46:454-456.

7. Ghosh J, Nanda RS. Evaluation of an intraoral maxillary molar distalization technique. Am J Orthod Dentofacial Orthop 1996;110:639-646.

8. Valentino TA, Borges GA, Borges LH, Vishal J, Martins LR, Correr-Sobrinho L. Dual resin cement Knoop hardness after different activation modes through dental ceramics. Braz Dent $\mathrm{J}$ 2010;21:104-110.

9. Reagan SE. Correcting space loss caused by severe decay: report of case. J Am Dent Assoc 1988;116:878-879.

10. van Gastel J, Quirynen M, Teughels W, Coucke W, Carels C. Longitudinal changes in microbiology and clinical periodontal variables after placement of fixed orthodontic appliances. J Periodontol 2008;79:2078-2086.

11. Nalbantgil D, Cakan DG, Oztoprak MO, Arun T. Perception of pain and discomfort during tooth separation. Aust Orthod J 2009;25:110-115.

12. Smidt A, Venezia E. Gaining adequate interdental space with modified elastic separating rings: rationale and technique. Quintessence Int 2002;33:409-414.

13. Garino F, Garino GB. Distalization of maxillary molars using the speed system: a clinical and radiological evolution. World J Orthod 2004;5:317-323. 